Situs Jurnal : $\underline{\text { http://ejournal.stiepancasetia.ac.id/index.php/jieb }}$

Jilid 5 Nomor 2 Juli 2019

Hal 220 - 237

\title{
SURVEI KEPUASAN MASYARAKAT TERHADAP PELAYANAN PUBLIK KANTOR DESA TATAH LAYAP KECAMATAN TATAH MAKMUR KABUPATEN BANJAR
}

\begin{abstract}
Ahmad Jazuli \& Siti Fatimah*
Abstract: Public services are very important, both in the form of public goods and public services. Services in the form of public goods can be facilities that support people's lives such as roads, clean water and so on. The higher the quality of service in the form of public goods, the people's lives will be good, meaning that there are no problems that hinder in carrying out daily activities. While services in the form of services are very much needed by the community, such as health and education services and transportation. The services at the Tatah Layap Village Office in the District of Tatah Makmur, Banjar Regency in the category of service quality "B" were meaningful, but there were still elements: from Permenpan RB No. 14 of 2017 is not good, namely: completion time, implementing behavior, handling complaints and input suggestions, infrastructure according to the community in Tatahn Layap Village, Tatah Makmur District, Banjar Regency.
\end{abstract}

Keywords: public services, quality of service, Tatah Lauap Village Office

Abstrak: Pelayanan publik sangatlah penting, baik dalam bentuk berwujud untuk masyarakat ataupun jasa untuk masyarakat. Pelayanan dalam bentuk berwujud untuk masyarakat bisa jadi berupa fasilitas yang mendukng kehidupan masyarakat, seperti jalan raya, air bersih dan lainnya. Semakin tinggi kualitas pelayanan dalam bentuk barang publik maka kehidupan masyarakat akan baik, artinya tidak ada masalah yang menghambat dalam melaksanakan kegiatan sehari-hari. Sementara pelayanan dalam bentuk jasa sangat dibutuhkan masyarakat, seperti pelayanan kesehatan dan pendidikan serta penyelenggaraan transportasi. Kualitas pelayanan di Kantor Desa Tatah Layap Kecamatan Tatah Makmur Kabupaten Banjar masuk dalam kategori "B", tetapi masih ada elemen kualitas pelayanan dari PermenpanRB No. 14 tahun 2017 yang masih belum bagus, berupa waktu penyelesaian, perilaku pelaksana, penanganan saran dan keluhan, infrastruktur menurut masyarakat Desa Tatah Layap Kecamatan Tatah Makmur Kabupaten Banjar.

Kata kunci : pelayanan publik, kualitas jasa, Kantor Desa Tatah Layap

\section{Latar Belakang}

Ditinjau dari kebutuhan masyarakat, pelayanan publik sangatlah penting, baik dalam bentuk barang publik maupun jasa publik. Pelayanan dalam bentuk barang publik dapat berupa fasilitas-fasilitas yang menunjang kehidupan masyarakat seperti jalan raya, air bersih dan lain sebagainya. Semakin tinggi kualitas pelayanan dalam bentuk barang publik maka kehidupan masyarakat akan baik, artinya tidak ada masalah yang menghambat dalam melaksanakan kegiatan sehari-hari. Sementara pelayanan dalam bentuk jasa sangat dibutuhkan masyarakat, seperti pelayanan kesehatan dan pendidikan serta penyelenggaraan transportasi. 
Pelayanan publik menurut Undang-Undang RI No. 25 Tahun 2009 tentang Pelayanan Publik adalah kegiatan atau rangkaian kegiatan dalam rangka pemenuhan kebutuhan pelayanan sesuai dengan peraturan perundang-undangan bagi setiap warga negara dan penduduk atas barang, jasa dan/atau pelayanan administratif yang disediakan oleh penyelenggara pelayanan publik.

Dalam penyelenggaraan pelayanan publik, orientasi pada kekuasaan yang amat kuat selama ini telah membuat birokrasi menjadi semakin jauh dari misinya untuk memberikan pelayanan publik. Birokrasi dan para pejabatnya lebih menempatkan dirinya sebagai penguasa daripada sebagai pelayan masyarakat. Akibatnya, sikap dan perilaku birokrasi dalam penyelenggaraan pelayanan publik cenderung mengabaikan aspirasi dan kepentingan masyarakat.

Tabel 1. Data Keluhan Masyarakat Kantor Desa Tatah Layap

\begin{tabular}{lll}
\hline \multicolumn{1}{c}{ Unsur } & Keluhan Masyarakat & Waktu Selesai \\
\hline \multirow{2}{*}{ Waktu Penyelesaian } & Surat kepemilikan Tanah & 3 Hari \\
\cline { 2 - 3 } & Surat Keterangan Pindah & 2 Hari \\
\cline { 2 - 3 } & Surat Keterangan Tidak Mampu & 1 Hari \\
\cline { 2 - 3 } & Surat Pengantar Nikah & 3 Hari \\
\hline Unsur & Keluhan Masyarakat & Keterangan \\
\cline { 2 - 3 } Prilaku Pelaksana & Keramahannya & Kurang Ramah \\
\cline { 2 - 3 } & Petugas/aparat di Kantor & Jarang ada \\
\hline Unsur & Keluhan Masyarakat & Keterangan \\
\cline { 2 - 3 } Sarana Pra Sarana & Tempat Parkir & Kecil dan panas \\
\cline { 2 - 3 } & Kursi Mengantri & Tidak Ada \\
\cline { 2 - 3 } & Kipas Angin & Tidak Ada \\
\hline
\end{tabular}

Hal ini ditunjukkan dengan masih munculnya berbagai keluhan masyarakat melalui media massa. Jika kondisi ini tidak direspon oleh pemerintah maka akan dapat menimbulkan citra yang kurang baik terhadap pemerintah sendiri. Mengingat fungsi utama pemerintah adalah melayani masyarakat maka pemerintah perlu terus berupaya meningkatkan kualitas pelayanan publik (permenpan RB Nomor 14 Tahun 2017).

Kebijakan pendayagunaan aparatur negara dalam upaya peningkatan kualitas pelayanan harus dilaksanakan secara konsisten dengan memperhatikan kebutuhan dan harapan masyarakat, sehingga pelayanan pemerintah kepada masyarakat dapat selalu diberikan secara cepat, tepat, murah, terbuka, sederhana dan mudah dilaksanakan serta tidak diskriminatif.

Oleh karena itu, upaya peningkatan kualitas pelayanan kepada masyarakat merupakan kegiatan yang dilaksanakan secara terus-menerus dan berkelanjutan oleh semua jajaran aparatur negara pada semua tingkatan pelayanan, sehingga mencapai kualitas yang diharapkan. Untuk mengetahui kinerja pelayanan aparatur pemerintah kepada masyarakat, maka perlu dilakukan penilaian atas pendapat masyarakat terhadap pelayanan tersebut melalui pengukuran Survei Kepuasan Masyarakat (SKM).

Menyusun survei kepuasan masyarakat (SKM) merupakan salah satu kegiatan dalam upaya meningkatkan pelayanan publik dan sebagai tolok ukur terhadap optimalisasi kinerja pelayanan publik oleh aparatur pemerintah kepada masyarakat. Untuk itu ditetapkan pedoman umum penyusunan survei kepuasan masyarakat unit pelayanan Instansi Pemerintah dengan Peraturan Menteri Pendayagunaan Aparatur Negara dan Reformasi dan Birokrasi Nomor: Permenpan RB/14/2017. 
Berdasarkan uraian dan persepsi inilah yang kemudian melatarbelakangi penulis untuk mengambil judul "Survei Kepuasan Masyarakat terhadap Pelayanan Publik di Kantor Desa Tatah Layap ". Diharapkan hasil dari SKM ini dapat menjadi masukan dan tolak ukur bagi unit pelaksana teknis di (Desa Tatah Layap) terhadap keberhasilan pelayanan umum untuk masyarakat.

Berdasarkan pada latar belakang yang telah dikemukakan, maka dapat dibuat pertanyaan penelitian untuk penelitian ini adalah:

1. Bagaimana hasil Survei Kepuasan Masyarakat terhadap Pelayanan Publik di Kantor Desa Tatah Layap Kecamatan Tatah Makmur Kabupaten Banjar?

2. Berdasarkan hasil Survei tersebut apa yang harus dilakukan Kantor Desa Tatah Layap Kecamatan Tatah Makmur Kabupaten Banjar?

\section{Kajian Literatur}

Survei Kepuasan Masyarakat (SKM) menurut Ratminto dan Winarsih (2015:222) adalah data dan informasi tentang tingkat kepuasan masyarakat yang diperoleh dari hasil pengukuran secara kuantitatif atas pendapat masyarakat dalam memperoleh pelayanan dari aparatur penyelenggara pelayanan publik dengan membandingkan antara harapan dan kebutuhannya

Survei kepuasan masyarakat (SKM) menurut Permenpan RB No 14 Tahun 2017 adalah kegiatan pengukuran secara komprehensif tentang tingkat kepuasan masyarakat terhadap kualitas layanan yang diberikan oleh penyelenggara pelayanan publik dimana sasaran pengukuran mencakup: penataan sistem, mekanisme dan prosedur pelayanan. Dengan demikian pelayanan dapat dilaksanakan secara lebih berkualitas, berdaya guna dan berhasil..

Sedangkan Bragan dalam Nugraha Arif (2015) memberikan alasan penggunaan Survei Kepuasan Pelanggan sebagai ukuran untuk mengetahui kualitas pelayanan adalah berdasarkan kebanyakan pendapat yang mengatakan bahwa untuk mengetahui program mutu, apapun bentuk organisasinya keberhasilan dari program mutu tersebut diukur dari kepuasan pelanggan".

Peningkatan kualitas pelayanan publik mengandung makna adanya perubahan mutu, kondisi, dari keadaan sekarang ke mutu yang lebih baik. Jadi kualitas dalam hal ini bersifat dinamis menyesuaikan dengan perkembangan situasi dan kondisi masyarakat. Menurut Mahmudi (2013:227) mengelompokkan tiga jenis pelayanan dari instansi pemerintah serta BUMN/BUMD. Pengelompokan jenis pelayanan tersebut didasarkan pada ciri-ciri dan sifat kegiatan serta produk pelayanan yang dihasilkan, yaitu:

1. Pelayanan Administratif, adalah jenis pelayanan yang diberikan oleh unit pelayanan berupa pencatatan, penelitian, pengambilan keputusan, dokumentasi, dan kegiatan tata usaha lainnya yang secara keseluruhan menghasilkan produk akhir berupa dokumen, misalnya sertifikat, ijin-ijin, rekomendasi, dan lain sebagainya.

2. Pelayanan Barang, adalah pelayanan yang diberikan oleh unit pelayanan berupa kegiatan penyediaan dan atau pengolahan barang berwujud fisik termasuk distribusi dan penyampaiannya kepada konsumen langsung (sebagai unit ataupun individu) dalam suatu sistem. Kegiatan tersebut menghasilkan produk akhir berwujud benda (fisik) misalnya pelayanan listrik, air bersih dan pelayanan telepon.

3. Pelayanan Jasa, adalah jenis pelayanan yang diberikan oleh unit pelayanan berupa sarana dan prasarana serta penunjangnya. Produk akhirnya berupa jasa yang mendatangkan manfaat bagi penerimanya secara langsung dan habis terpakai dalam jangka waktu tertentu. Misalnya pelayanan perbankan, pelayanan pos dan pelayanan pemadam kebakaran.

Kesimpulan dari berberapa jenis pelayanan publik yang diberikan oleh pemerintah kepada masyarakat diatas, terdapat tiga jenis yaitu pelayanan administratif, pelayanan barang 
dan pelayanan jasa. Berdasarkan ketiga jenis tersebut, pelayanan di Kantor Desa Tatah Layap Kabupaten Banjar termasuk kedalam kategori pelayanan administratif .

Pada dasarnya cukup banyak karakteristik suatu pelayanan dimana karakteristik pelayanan mempunyai kekuatan untuk mempengaruhi tingkat kepuasan dan penampilan kerja karyawan. Hal ini dapat dilihat pada berbagai perumusan karakteristik yang dibuat oleh para ahli. Zeithaml, Berry dan Parasuraman dalam Nugraheni Arif (2015) mengidentifikasikan lima karakteristik yang digunakan oleh para pelanggan dalam mengevaluasi kualitas jasa, yaitu:

1. Bukti langsung (tangible)

Tangible adalah faktor yang mempengaruhi kepuasan pelanggan dari segi visual (berhubungan dengan lingkungan fisik). Tangible yang baik akan mempengaruhi persepsi pelanggan. Pada saat yang bersamaan aspek tangible ini juga merupakan salah satu sumber yang mempengaruhi harapan pelanggan. Aspek tangible meliputi fasilitas fisik, perlengkapan, pegawai, dan sarana komunikasi.

2. Kehandalan (reliability)

Reliability yaitu kemampuan memberikan pelayanan yang dijanjikan dengan segera dan memuaskan. Reliability berarti perusahaan menepati apa yang dijanjikan, baik mengenai pengantaran, pemecahan masalah, dan harga. Reliabilitas meliputi dua aspek utama, yaitu konsistensi kinerja (performance) dan sifat dapat dipercaya (dependability). Hal ini berarti perusahaan mampu menyampaikan jasanya secara benar sejak awal, memenuhi janjinya secara akurat dan andal, menyampaikan data secara tepat dan mengirimkan tagihan yang akurat.

3. Daya tanggap (responsiveness)

Daya tanggap yaitu keinginan para staff untuk membantu para pelanggan dan memberikan pelayanan dengan tanggap. Beberapa contohnya adalah ketepatan waktu pelayanan, kecepatan memanggil kembali pelanggan, dan penyampaian layanan secara cepat. Dimensi ini menegaskan perhatian dan kecepatan waktu dalam hubungannya dengan permintaan pelanggan, pelayanan, komplain dari masalah yang terjadi.

4. Jaminan (assurance)

Jaminan yang dimaksud adalah perilaku karyawan atau petugas pelayanan mampu menumbuhkan kepercayaan pelanggan terhadap perusahaan dan perusahaan dapat menciptakan rasa aman bagi para pelanggannya. Jaminan juga berarti bahwa para karyawan selalu bersikap sopan dan menguasai pengetahuan dan ketrampilan yang dibutuhkan untuk menanggapi setiap pertanyaan atau masalah pelanggan. Jaminan ini mencangkup kemampuan, kesopanan, dan sifat dapat dipercaya yang dimiliki para staff, bebas dari bahaya, resiko atau keragu-raguan.

5. Empati

Empati berarti perusahaan memahami masalah paran pelanggannya dan bertindak demi kepentingan pelanggan, serta memberikan perhatian personal kepada para pelanggan dan memiliki jam operasi yang nyaman. Empati dalam pelayanan meliputi kemudahan dalam melakukan hubungan, komunikasi yang baik, dan memahami kebutuhan para pelanggan. Berdasarkan uraian tersebut, dapat disimpulkan bahwa pelayanan yang diberikan oleh Kantor Desa mungkin akan mempengaruhi tingkat kepuasan pelanggan dari segi bukti langsung, kehandalan, daya tanggap, jaminan dan empati yang diberikan selama proses pelayanan.

Pelayanan yang baik pada akhirnya akan mampu memberikan kepuasan kepada masyarakat. Pelayanan yang optimal pada akhirnya juga akan mampu meningkatkan image organisasi sehingga citra organisasi di mata masyarakat terus meningkat. Adanya citra organisasi yang baik, maka segala yang dilakukan oleh organisasi akan dianggap baik pula. 
Menurut Kasmir dalam Nugraheni Arif (2015), Faktor utama yang mempengaruhi pelayanan adalah sumber daya manusia. Artinya peranan manusia (karyawan) yang melayani masyarakat merupakan faktor utama karena hanya dengan manusialah pelanggan dapat berkomunikasi secara langsung dan terbuka.

Menurut Atep Adya Barata (2003: 37), "Kualitas pelayanan terbagi menjadi dua bagian yaitu kualitas pelayanan internal dan eksternal". Masing-masing bagian tersebut dipengaruhi oleh beberapa faktor yang cukup penting, yaitu sebagai berikut:

1. Faktor yang mempengaruhi kualitas pelayanan internal (interaksi pegawai organisasi), yaitu pola manajemen umum organisasi, penyediaan fasilitas pendukung,pengembangan sumber daya manusia, iklim kerja dan keselarasan hubungan kerja, serta pola insentif.

2. Faktor yang mempengaruhi kualitas pelayanan eksternal (pelanggan eksternal), yaitu pola layanan dan tata cara penyediaan layanan, pola layanan distribusi jasa, pola layanan penjualan jasa, dan pola layanan dalam penyampaian jasa.

Menurut Vincent Gaspersz (2011: 41), terdapat faktor-faktor yang mempengaruhi persepsi dan ekspektasi pelanggan terhadap pelayanan, yaitu:

1. Kebutuhan dan keinginan yang berkaitan dengan hal-hal yang dirasakan pelanggan ketika ia sedang mencoba melakukan transaksi dengan perusahaan.

2. Pengalaman masa lalu ketika menggunakan jasa dari perusahaan.

3. Pengalaman dari teman-teman, dimana mereka akan menceritakan tentang kualitas pelayanan yang akan diterimanya.

4. Komunikasi melalui iklan dan pemasaran juga mempengaruhi persepsi dari pelanggan terhadap jasa yang akan diterimanya.

Berdasarkan uraian tersebut, dapat disimpulkan bahwa untuk meningkatkan kualitas pelayanan banyak faktor yang mempengaruhi antara lain sumber daya manusia, kesadaran, aturan, organisasi, ketrampilan dan kemampuan, sarana pelayanan, serta pengalaman pelanggan. Selain itu faktor internal dan eksternal juga menjadi penting dan berpengaruh dalam mewujudkan pelayanan yang berkualitas bagi setiap pengguna.

\section{Metode Penelitian}

Penelitian dengan judul "Survei Kepuasan Masyarakat Terhadap Pelayanan Publik di Kantor Desa Tatah Layap Kecamatan Tatah Makmur Kabupaten Banjar" adalah penelitian survey, jenis survei secara umum ada 2 yaitu:

1. Survei yang lengkap, yaitu mencakup seluruh populasi batau elemen-elemen yang menjadi objek penelitian. Survey ini disebut sensus.

2. Survei yang hanya menggunakan sebagian kecil dari populasi, atau hanya menggunakan sampel dari populasi. Jenis ini sering disebut sebagai sample survey method.

Menurut Sugiyono pengertian populasi adalah wilayah generalisasi yang terdiri atas: Obyek/subyek yang mempunyai kualitas dan karakteristik tertentu yang ditetapkan oleh peneliti untuk dipelajari kemudian ditarik kesimpulannya (Sugiyono, 2011:80). Berdasarkan teori tersebut populasi yang diambil untuk penelitian ini ada 270 orang dari penduduk wilayah Desa Tatah Layap yang menggunakan pelayanan di Kantor Desa pada tahun 2018. Menurut Sugiyono sampel adalah bagian atau jumlah dan karakteristik yang dimiliki oleh populasi tersebut. Bila populasi besar, dan peneliti tidak mungkin mempelajari semua yang ada pada populasi, misal karena keterbatasan dana, tenaga dan waktu, Maka peneliti akan mengambil sampel dan populasi itu. Apa yang dipelajari dari sampel itu, Kesimpulannya akan diberlakukan 
untuk populasi. Untuk itu sampel yang di ambil dari populasi harus betul-betul representative (sugiyono, 2011)

Jumlah sampel yang diambil dalam penelitian ini sesuai dengan rumus morgan dan krejcie dari acuan Permenpan RB No. 14 Tahun 2017 dari Penduduk Desa Tatah Layap Kabupaten Banjar adalah sebagai berikut:

$\mathrm{S}=\left\{\alpha \lambda^{2} . \mathrm{N} . \mathrm{P} . \mathrm{Q}\right\} /\left\{\mathrm{d}^{2}(\mathrm{~N}-1)+\lambda^{2} . \mathrm{P} . \mathrm{Q}\right\}$

Dimana :

$\mathrm{S}=$ Jumlah Sampel

$\lambda^{2}=$ Lambda (Faktor Pengali) dengan $\mathrm{dk}=1$, taraf kesalahan bias $1 \%, 5 \%, 10 \%$

$\mathrm{N}=$ Populasi

$\mathrm{P}($ Populasi menyebar normal $)=\mathrm{Q}=0,5$

$\mathrm{D}=0,0$

Dari rumus Krejci dan Morgan diatas maka sampel yang di ambil dalam penelitian ini berjumlah 159 orang.

Data yang digunakan dalam penelitian ini harus dapat dipertanggung jawabkan kebenarannya, serta dapat memberi gambaran secara menyeluruh tentang masalah yang diteliti . Dalam penelitian ini si penulis mengklarifikasikan data atas dua jenis yaitu :

1. Data Kuantitaif yaitu data yang dapat di ukur dalam skala numerik (angka) yang berkaitan dengan masalah yang di teliti, seperti nilai rata-rata dari hasil survei kepuasan masyarakat

2. Data Kualitatif yaitu data yang dinyatakan dalam bentuk kata, kalimat gambar serta tidak dapat di ukur dalam skala numerik, misalnya keterangan yang di peroleh dari hasil wawancara dengan responden serta informasi yang di peroleh dari pihak lain yang berkaitan dengan masalah yang di bahas.

Data yang digunakan dalam penelitian ini adalah :

1. Data Primer, yaitu data yang didapat dari hasil observasi langsung ke organisasi (kantor) dan wawancara yang di lakukan, yaitu terdiri dari keadaan sesungguhnya di Kantor Desa Tatah Layap Kabupaten Banjar

2. Data Sekunder, yaitu data yang didapat dari dokumen atau laporan orang, organisasi, kantor , media massa, jumlah petugas, absensi petugas, jam kerja petugas.

Metode kepustakaan merupakan metode pengumpulan data berdasarkan laporan masyarakat yaitu sms, telpon, media massa yang berkaitan dengan judul tugas akhir ini dan sumber data tertulis lainnya yang ada di Kantor Desa Tatah Layap, yang berhubungan dengan pokok pembahasan tugas akhir ini dan dijadikan sebagai dasar perbandingan antara data yang penulis dapatkan dilapangan.

Penelitian lapangan merupakan penelitian yang dilakukan dengan mengumpulkan data dan informasi yang diperoleh langsung dari responden dan mengambil secara langsung tugastugas yang berhubungan dengan prosedur Pelayanan Publik pada Kantor Desa Tatah Layap.

Dalam mengumpulkan data tekhnik yang digunakan adalah :

\section{Kuesioner}

Kuesioner, pengumpulan data dengan menggunakan daftar pertanyaan yang digunakan untuk mengetahui tingkat kepuasan masyarakat. Pedoman survei kepuasan mayarakat terhadap penyelenggaraan pelayanan publik suudah di atur dalam Permenpan RB nomor 14 tahun 2017. 


\section{Observasi}

Observasi adalah suatui tekhnik pengumpulan data dengan cara mengamati hal-hal/objek yang berhubungan dengan masalah penelitian.

3. Wawancara

Wawancara adalah suatu tekhnik pengumpulan data dengan mengadakan tanya jawab secara langsung terhadap responden yang berkaitan dengan permasalahan dan segala pertanyaan di fokuskan pada permasalahan.

\section{Dokumentasi}

Dokumentasi adalah suatu tekhnik pengumpulan data dari catatan atau arsip yang berhubungan dengan objek penelitian.

Pengertian variabel menurut Sugiyono adalah sesuatu hal yang berbentuk apa saja yang ditetapkan peneliti untuk dipelajari sehingga diperoleh informasi tentang hal tersebut, dan kemudian ditarik kesimpulannya. Variabel penelitian ini terdiri dari variabel dependen/terikat (Y) yaitu Pelayanan Publik dan variabel independen/bebas yaitu Kepuasan Masyarakat. Definisi operasional variabel menurut Suprapto (2003) adalah terdiri dari upaya mereduksi konsep dari tingkat abstraksi (tidak jelas) menuju ke tingkat yang lebih konkret, dengan jalan merinci atau memecah menjadi dimensi kemudian elemen, diikuti dengan upaya menjawab pertanyaan-pertanyaan apa yang terkait dengan elemen-elemen, dimensi dari suatu konsep.

1. Kepuasan Masyarakat (X)

Kepuasan Masyarakat adalah ukuran kepuasan masyarakat terhadap pelayanan publik yang diberikan oleh petugas dan instansi seperti yang diharapkan. Indikator Tingkat Kepuasan Masyarakat dalam Permenpan RB No: 14 Tahun 2017 Sebagai Berikut:

a. Persyaratan (X1)

Persyaratan adalah syarat yang harus dipenuhi dalam pengurusan suatu jenis pelayanan, baik persyaratan teknis maupun administratif.

b. Sistem, Mekanisme, dan Prosedur (X2)

Prosedur adalah tata cara pelayanan yang dibakukan bagi pemberi dan penerima pelayanan, termasuk pengaduan.

c. Waktu Penyelesaian (X3)

Waktu Penyelesaian adalah jangka waktu yang diperlukan untuk menyelesaikan seluruh proses pelayanan dari setiap jenis pelayanan.

d. Biaya/Tarif (X4)

Biaya/Tarif adalah ongkos yang dikenakan kepada penerima layanan dalam mengurus dan/atau memperoleh pelayanan dari penyelenggara yang besarnya ditetapkan berdasarkan kesepakatan antara penyelenggara dan masyarakat.

e. Produk Spesifikasi Jenis Pelayanan (X5)

Produk spesifikasi jenis pelayanan adalah hasil pelayanan yang diberikan dan diterima sesuai dengan ketentuan yang telah ditetapkan. Produk pelayanan ini merupakan hasil dari setiap spesifikasi jenis pelayanan.

f. Kompetensi Pelaksana (X6)

Kompetensi Pelaksana adalah kemampuan yang harus dimiliki oleh pelaksana meliputi pengetahuan, keahlian, keterampilan, dan pengalaman.

g. Perilaku Pelaksana (X7)

Perilaku Pelaksana adalah sikap petugas dalam memberikan pelayanan.

h. Penanganan Pengaduan, Saran dan Masukan (X8)

Penanganan pengaduan, saran dan masukan, adalah tata cara pelaksanaan penanganan pengaduan dan tindak lanjut.

i. Sarana dan prasarana (X9) 
Sarana adalah segala sesuatu yang dapat dipakai sebagai alat dalam mencapai maksud dan tujuan. Prasarana adalah segala sesuatu yang merupakan penunjang utama terselenggaranya suatu proses (usaha, pembangunan, proyek). Sarana digunakan untuk benda yang bergerak (komputer, mesin) dan prasarana untuk benda yang tidak bergerak (gedung).

\section{Pelayanan Publik (Y)}

Adalah segala bentuk pelayanan yang dilaksanakan instansi dipusat, didaerah dan di Badan Usaha Milik Negara (BUMN) dalam bentuk bidang jasa baik dalam usaha pemenuhan kebutuhan masyarakat maupun dalam rangka pelaksanaan peraturan perundang- undangan.

Penyusunan survei kepuasan masyarakat ini diterapkan pada Kantor Desa Tatah Layap Kabupaten Banjar dengan mengadakan 159 (seratus lima puluh sembilan) kuesioner kepada responden yang menggunakan jasa pelayanan publik di Kantor Desa Tatah Layap Kabupaten Banjar, dengan menggunakan pedoman penyusunan Survei Kepuasan Masyarakat (SKM) unit pelayanan instansi pemerintah Permenpan RB Nomor 14 Tahun 2017.

Setiap pertanyaan survei masing-masing unsur diberi nilai. Nilai dihitung dengan menggunakan "nilai rata-rata tertimbang" masing-masing unsur pelayanan. Dalam penghitungan survei kepuasan masyarakat terhadap unsur-unsur. Nilai penimbang ditetapkan dengan rumus, sebagai berikut:

Bobot Nilai Rata-Rata Tertimbang $=\frac{\text { Jumlah Bobot }}{\text { Jumlah Unsur }}=\frac{1}{X}=\mathrm{N}$

Untuk memperoleh nilai SKM unit pelayanan digunakan pendekatan nilai rata-rata tertimbang dengan rumus sebagai berikut:

$\mathrm{SKM}=\frac{\text { Total dari Nilai } \text { Persepsi per Unsur }}{\text { Total Unsur yang Terisi }} \times$ Nilai Penimbang

Untuk memudahkan interpretasi terhadap penilaian SKM yaitu antara 25 - 100, maka hasil penilaian tersebut di atas dikonversikan dengan nilai dasar 25 , dengan rumus sebagai berikut:

SKM Unit Pelayanan x 25

Tabel 2. Kategorisasi Nilai Mutu Pelayanan

\begin{tabular}{ccccc}
\hline $\begin{array}{c}\text { NILAI } \\
\text { PERSEPSI }\end{array}$ & $\begin{array}{c}\text { NILAI } \\
\text { INTERVAL } \\
(\mathrm{NI})\end{array}$ & $\begin{array}{c}\text { NILAI INTERVAL } \\
\text { KONVERSI } \\
(\text { NIK })\end{array}$ & $\begin{array}{c}\text { MUTU } \\
\text { PELAYANAN } \\
(\mathrm{x})\end{array}$ & $\begin{array}{c}\text { MUTU } \\
\text { PELAYANAN } \\
(\mathrm{x})\end{array}$ \\
\hline 1 & $1,00-2,5996$ & $25,00-64,99$ & $\mathrm{D}$ & Tidak Baik \\
\hline 2 & $2,60-3,064$ & $65,00-76,60$ & $\mathrm{C}$ & Kurang Baik \\
\hline 3 & $3,0644-3,532$ & $76,61-88,30$ & $\mathrm{~B}$ & Baik \\
\hline & & & JIEB, Jilid 5, No 2, Juli 2019 & 227 \\
& & & &
\end{tabular}




\begin{tabular}{lllll}
\hline 4 & $3,5324-4,00$ & $88,31-100$ & A & Sangat Baik \\
\hline
\end{tabular}

\section{Hasil Penelitian dan Pembahasan}

Penelitian ini dilaksanakan di Kantor Desa Tatah Layap Kecamatan Tatah Makmur Kabupaten Banjar yang beralamat di jalan Tatah Layap Rt. 005 Rw. 002 pada bulan September 2018 sampai dengan Januari 2019. Responden penelitian ini adalah masyarakat yang menjadi pengguna pelayanan di kantor desa Tatah Layap Kecamatan Tatah Makmur Kabupaten Banjar sebanyak 159 orang. Adapun karakteristik responden sebagai berikut:

1. Karakteristik Responden Berdasarkan Jenis Kelamin

Bahwa frekuensi karakteristik responden berdasarkan jenis kelamin laki-laki sebanyak 94 orang dengan proporsi 59\%. Sedangkan frekuensi perempuan sebanyak 65 orang dengan proporsi $41 \%$.

2. Karakteristik responden berdasarkan Jam Survei

Bahwa frekuensi karakteristik responden berdasarkan jam survei jam 08.00-12.00 sebanyak 47 orang dengan proporsi 30\%. Sedangkan frekuensi jam 13.00-17.00 sebanyak 112 orang dengan proporsi $70 \%$.

3. Karakteristik responden berdasarkan umur

Bahwa frekuensi karakteristik responden berdasarkan umur terendah terdapat pada interval umur kurang dari atau sama dengan 20 tahun sebanyak 27 orang dengan proporsi $17 \%$. Sedangkan frekuensi tertinggi terdapat pada interval umur lebih dari atau sama dengan 31 tahun sebanyak 52 orang dengan proporsi $33 \%$.

4. Karakteristik kresponden berdasarkan jenis pendidikan

Bahwa frekuensi karakteristik responden berdasarkan jenis pendidikan terendah terdapat pada jenis pendidikan S1 sebanyak 16 orang dengan proporsi $10 \%$. Sedangkan frekuensi tertinggi terdapat pada jenis pendidikan SMP sebanyak 54 orang dengan proporsi $34 \%$.

5. Karakteristik responden berdasarkan jenis pekerjaan

Bahwa frekuensi karakteristik responden berdasarkan jenis pekerjaan terendah terdapat pada jenis pekerjaan PNS 13 orang dengan proporsi 8\%. Sedangkan frekuensi tertinggi terdapat pada jenis pekerjaan Buruh Tani sebanyak 85 orang dengan proporsi 53\%.

6. Karakteristik responden berdasarkan jenis layanan

Bahwa frekuensi karakteristik responden berdasarkan jenis layanan terendah terdapat pada jenis layanan surat keterangan pindah 18 orang dengan proporsi $11 \%$. Sedangkan frekuensi tertinggi terdapat pada jenis layanan surat pengantar nikah sebanyak 55 orang dengan proporsi $35 \%$.

Berdasarkan pengukuran terhadap 9 unsur pelayanan (U), diperoleh perhitungan Survei Kepuasan Masyarakat (SKM) Kantor Desa Tatah Layap Kecamatan Tatah Makmur Kabupaten Banjar mengacu pada data perolehan Survei Kepuasan Masyarakat per-unsur pelayanan sebagai berikut:

1. Menghitung jumlah nilai per-unsur pelayanan
a. Persyaratan $(\mathrm{U} 1)=510$
b. Sistem, Mekanisme dan Prosedur $(\mathrm{U} 2)=500$
c. Waktu Penyelesaian (U3) $=466$
d. Biaya $/$ Tarif $(\mathrm{U} 4)=513$
e. Produk Spesifikasi Jenis Pelayanan $($ U5) $=508$
f. Kompetensi Pelaksana (U6) $=504$
g. Prilaku Pelaksana $($ U7) $=485$
h. Penanganan Pengaduan, Saran dan Masukan $($ U8) $=486$ 
i. Sarana dan Prasarana (U9) $=465$

2. Menghitung Nilai Rata-Rata Per-unsur:
NRR U1 = $510: 159=3.21$
NRR U2 $=500: 159=3.14$
NRR U3 $=466: 159=2.93$
NRR U4 $=513: 159=3.23$
NRR U5 $=508: 159=3.19$
NRR U6 $=504: 159=3.17$
NRR U7 $=485: 159=3.05$
NRR U8 $=486: 159=3.06$
NRR U9 $=465: 159=2.92$

3. Menghitung Nilai Rata-rata Tertimbang:
SKM U1 = 510: $159 \times 0.11=0.35$
SKM U2 $=500: 159 \times 0.11=0.35$
SKM U3 $=466: 159 \times 0.11=0.32$
SKM U4 $=513: 159 \times 0.11=0.35$
SKM U5 $=508: 159 \times 0.11=0.35$
SKM U6 $=504: 159 \times 0.11=0.35$
SKM U7 $=485: 159 \times 0.11=0.34$
SKM U8 $=486: 159 \times 0.11=0.34$
SKM U9 $=465: 159 \times 0.11=0.32$

Total Nilai Indeks adalah $=0.35+0.35+0.32+0.35+0.35+0.35+0.34+0.34+0.32=$ 3.07

4. Menghitung Nilai Survei Kepuasan Masyarakat Untuk memudahkan interpretasi terhadap penilaian Survei Kepuasan Masyarakat yaitu antara 25 - 100, maka hasil penilaian tersebut di atas dikonversikan dengan nilai dasar 25.

Nilai SKM setelah di konversi = Nilai Indeks x 25

Nilai SKM setelah di konversi $=3.07$ x $25=76.75$

Berdasarkan kategorisasi mutu pelayanan, maka Kantor Desa Tatah Layap Kecamatan Tatah Makmur Kabupaten Banjar memperoleh hasil nilai konversi SKM sebesar 76.75 , kinerja unit pelayanan Kantor Desa Tatah Layap Kecamatan Tatah Makmur Kabupaten Banjar berada dalam mutu pelayanan "B" dengan kategori "BAIK".

Nilai SKM unsur pelayanan menunjukan penilaian masyarakat terhadap unsur pelayanan tersebut , Berikut ini hasil penilaian Survei Kepuasan Masyarakat (SKM) untuk masing-masing unsur:

1. Persyaratan Pelayanan Kantor Desa Tatah Layap Kecamatan Tatah Makmur Kabupaten Banjar

Hasil perhitungan SKM untuk unsur persyaratan pelayanan pada Kantor Desa Tatah Layap Kecamatan Tatah Makmur Kabupaten Banjar adalah sebagai berikut : 
Nilai Rata-rata Perunsur $=$ Jumlah Nilai Perunsur : Jumlah Responden

$$
=510: 159=3.21
$$

Nilai SKM unsur persyaratan pelayanan $=$ NRR $\times 25$

$$
=3.21 \times 25=80.25
$$

2. Sistem, Mekanisme dan Prosedur Kantor Desa Tatah Layap Kecamatan Tatah Makmur Kabupaten Banjar

Hasil perhitungan SKM untuk unsur sistem, mekanisme dan prosedur pada Kantor Desa Tatah Layap Kecamatan Tatah Makmur Kabupaten Banjar adalah sebagai berikut :

Nilai Rata-rata Perunsur $=$ Jumlah Nilai Perunsur : Jumlah Responden

$$
=500: 159=3.14
$$

Nilai SKM unsur persyaratan pelayanan $=$ NRR $\times 25$

$$
=3.14 \times 25=79.50
$$

3. Waktu Penyelesaian Kantor Desa Tatah Layap Kecamatan Tatah Makmur Kabupaten Banjar Hasil perhitungan SKM untuk unsur waktu penyelesaian pada Kantor Desa Tatah Layap Kecamatan Tatah Makmur Kabupaten Banjar adalah sebagai berikut :

Nilai Rata-rata Perunsur = Jumlah Nilai Perunsur : Jumlah Responden

$$
=466: 159=2.93
$$

Nilai SKM unsur persyaratan pelayanan $=$ NRR $\times 2$

$$
=2.93 \times 25=73.25
$$

4. Biaya/Tarif Kantor Desa Tatah Layap Kecamatan Tatah Makmur Kabupaten Banjar Hasil perhitungan SKM untuk unsur biaya/tarif pada Kantor Desa Tatah Layap Kecamatan Tatah Makmur Kabupaten Banjar adalah sebagai berikut :

Nilai Rata-rata Perunsur $=$ Jumlah Nilai Perunsur : Jumlah Responden

$$
=513: 159=3.23
$$

Nilai SKM unsur persyaratan pelayanan $=$ NRR $\times 25$

$$
=3.23 \times 25=80.50
$$

5. Produk Spesifikasi Jenis Pelayanan Kantor Desa Tatah Layap Kecamatan Tatah Makmur Kabupaten Banjar

Hasil perhitungan SKM untuk unsur produk spesifikasi jenis pelayanan pada Kantor Desa Tatah Layap Kecamatan Tatah Makmur Kabupaten Banjar adalah sebagai berikut :

Nilai Rata-rata Perunsur $=$ Jumlah Nilai Perunsur : Jumlah Responden

$$
=508: 159=3.19
$$

Nilai SKM unsur persyaratan pelayanan $=$ NRR $\times 25$

$$
=3.19 \times 25=79.75
$$


6. Kompetensi Pelaksana Kantor Desa Tatah Layap Kecamatan Tatah Makmur Kabupaten Banjar

Hasil perhitungan SKM untuk unsur kompetensi pelaksana pada Kantor Desa Tatah Layap Kecamatan Tatah Makmur Kabupaten Banjar adalah sebagai berikut :

Nilai Rata-rata Perunsur $=$ Jumlah Nilai Perunsur $:$ Jumlah Responden

$$
=504: 159=3.17
$$

Nilai SKM unsur persyaratan pelayanan $=$ NRR $\times 25$

$$
=3.17 \times 25=79.25
$$

7. Perilaku Pelaksana Kantor Desa Tatah Layap Kecamatan Tatah Makmur Kabupaten Banjar Hasil perhitungan SKM untuk unsur perilaku pelaksana pada Kantor Desa Tatah Layap Kecamatan Tatah Makmur Kabupaten Banjar adalah sebagai berikut :

Nilai Rata-rata Perunsur $=$ Jumlah Nilai Perunsur : Jumlah Responden

$$
=485: 159=3.05
$$

Nilai SKM unsur persyaratan pelayanan $=$ NRR $\times 25$

$$
=3.05 \times 25=76.25
$$

8. Penanganan Pengaduan, Saran dan Masukan Kantor Desa Tatah Layap Kecamatan Tatah Makmur Kabupaten Banjar

Hasil perhitungan SKM untuk unsur penanganan pengaduan, saran dan masukan pada Kantor Desa Tatah Layap Kecamatan Tatah Makmur Kabupaten Banjar adalah sebagai berikut :

Nilai Rata-rata Perunsur $=$ Jumlah Nilai Perunsur : Jumlah Responden

$$
=486: 159=3.06
$$

Nilai SKM unsur persyaratan pelayanan $=$ NRR x $25=3.06 \times 25=76.50$

9. Sarana dan Prasarana Kantor Desa Tatah Layap Kecamatan Tatah Makmur Kabupaten Banjar

Hasil perhitungan SKM untuk unsur sarana dan prasarana pada Kantor Desa Tatah Layap Kecamatan Tatah Makmur Kabupaten Banjar adalah sebagai berikut:

Nilai Rata-rata Perunsur $=$ Jumlah Nilai Perunsur : Jumlah Responden

$$
=465: 159=2.92
$$

Nilai SKM unsur persyaratan pelayanan $=$ NRR $\times 25$

$$
=2.92 \times 25=73.00
$$

Penilitian ini bertujuan untuk mengetahui pelayanan kantor desa Tatah Layap Kecamatan Tatah Makmur Kabupaten Banjar, berdasarkan kepuasan masyarakat yang diukur menggunakan survei kepuasan masyarakat permenpan RB No 14 Tahun 2017. Hasil penelitian menunjukan bahwa pelayanan kantor desa Tatah Layap Kecamatan Tatah Makmur Kabupaten Banjar berada pada tingkat yang baik. Hal ini ditunjukan dengan nilai survei kepuasan 
masyarakat (SKM) dari 9 (sembilan) unsur SKM sebesar 3.07 dengan nilai koversi SKM sebesar 76.75 yang bermakna baik .

Indikator yang memiliki nilai SKM tertinggi adalah biaya/tariff pelayanan dengan nilai SKM sebesar 3.23 dengan nilai konversi SKM sebesar 80.50. Sedangkan indikator yang memiliki nilai SKM terendah adalah indikator sarana dan prasarana dengan nilai SKM sebesar 2.92 dan nilai konversi SKM sebesar 73.00.

Pembahasan lebih rinci dari masing-masing indikator adalah sebagai berikut:

1. Persyaratan Pelayanan Kantor Desa Tatah Layap Kecamatan Tatah Makmur Kabupaten Banjar

Persyaratan pelayanan Kantor Desa Tatah Layap Kecamatan Tatah Makmur Kabupaten Banjar dijabarkan sesuai atau tidaknya syarat yang dibutuhkan dengan pelayanan yang masyarakat inginkan. Hasil penelitian menunjukan bahwa persyaratan pelayanan Kantor Desa Tatah Layap Kecamatan Tatah Makmur Kabupaten Banjar sudah sesuai dengan pelayanan yang di harapkan masyarakat atau baik. Hal tersebut dapat dilihat dari nilai Survei Kepuasan Masyarakat (SKM) untuk persyaratan pelayanan sebesar 3.21 dengan nilai konversi SKM sebesar 80.25 yang bermakna baik.

2. Prosedur pelayanan Kantor Desa Tatah Layap Kecamatan Tatah Makmur Kabupaten Banjar Prosedur pelayanan Kantor Desa Tatah Layap Kecamatan Tatah Makmur Kabupaten Banjar dari segi kemudahan mendapatkan informasi mengenai prosedur pelayanan dan kemudahan prosedur/tahapan alur pelayanan di Kantor Tatah Layap Kecamatan Tatah Makmur Kabupaten Banjar. Hasil penelitian menunjukan bahwa prosedur pelayanan Kantor Desa Tatah Layap Kecamatan Tatah Makmur Kabupaten Banjar sudah sesuai dengan pelayanan yang di harapkan masyarakat. Hal tersebut dapat dilihat dari nilai Survei Kepuasan Masyarakat (SKM) untuk prosedur pelayanan sebesar 3.14 dengan nilai konversi SKM sebesar 79.50 yang bermakna baik.

3. Waktu Penyelesaian Kantor Desa Tatah Layap Kecamatan Tatah Makmur Kabupaten Banjar.

Waktu penyelesaian Kantor Desa Tatah Layap Kecamatan Tatah Makmur Kabupaten dijabarkan dalam pernyataan mengenai kecepatan waktu penyelesaian. Hasil penelitian menunjukan bahwa waktu penyelesaian Kantor Desa Tatah Layap Kecamatan Tatah Makmur Kabupaten Banjar belum sesuai dengan pelayanan yang di harapkan masyarakat. Hal tersebut dapat dilihat dari nilai Survei Kepuasan Masyarakat (SKM) untuk waktu penyelesaian sebesar 2.93 dengan nilai konversi SKM sebesar 73.25 yang bermakna kurang baik.

4. Biaya/Tarif Kantor Desa Tatah Layap Kecamatan Tatah Makmur Kabupaten Banjar Biaya/tarif Kantor Desa Tatah Layap Kecamatan Tatah Makmur Kabupaten Banjar dijabarkan dengan biaya yang ditetapkan. Hasil penelitian menunjukan bahwa Biaya/tarif kantor desa Tatah Layap Kecamatan Tatah Makmur Kabupaten Banjar sudah sesuai atau baik. Hal tersebut dapat dilihat dari nilai Survei Kepuasan Masyarakat (SKM) untuk Biaya/tarif sebesar 3.23 dengan nilai konversi SKM sebesar 80.50 yang bermakna baik.

5. Produk Spesifikasi Jenis Pelayanan Kantor Desa Tatah Layap Kecamatan Tatah Makmur Kabupaten Banjar

Produk spesifikasi jenis pelayanan Kantor Desa Tatah Layap Kecamatan Tatah Makmur Kabupaten Banjar dijabarkan dalam pernyataan mengenai kesesuaian antara hasil pelayanan 
yang diberikan dengan ketentuan yang telah ditetapkan. Hasil penelitian menunjukan bahwa produk spesifikasi jenis pelayanan di Kantor Desa Tatah Layap Kecamatan Tatah Makmur Kabupaten Banjar baik. Hal tersebut dapat dilihat dari nilai Survei Kepuasan Masyarakat (SKM) untuk Produk spesifikasi jenis pelayanan sebesar 3.19 dengan nilai konversi SKM sebesar 79.75 yang bermakna baik.

6. Kompetensi Pelaksana Kantor Desa Tatah Layap Kecamatan Tatah Makmur Kabupaten Banjar

Kompetensi pelaksana Kantor Desa Tatah Layap Kecamatan Tatah Makmur Kabupaten Banjar dijabarkan dalam pernyataan mengenai kemampuan petugas dalam memberikan pelayanan. Hasil penelitian menunjukan bahwa Kompetensi pelaksana di kantor desa Tatah Layap Kecamatan Tatah Makmur Kabupaten Banjar baik. Hal tersebut dapat dilihat dari nilai Survei Kepuasan Masyarakat (SKM) untuk kompetensi pelaksana sebesar 3.17 dengan nilai konversi SKM sebesar 79.75 yang bermakna baik.

7. Perilaku Pelaksana Kantor Desa Tatah Layap Kecamatan Tatah Makmur Kabupaten Banjar Perilaku pelaksana Kantor Desa Tatah Layap Kecamatan Tatah Makmur Kabupaten Banjar dijabarkan dalam pernyataan mengenai sikap kesopanan dan keramahan petugas dalam memberikan pelayanan. Hasil penelitian menunjukan bahwa perilaku pelaksana Kantor Desa Tatah Layap Kecamatan Tatah Makmur Kabupaten Banjar belum baik. Hal tersebut dapat dilihat dari nilai Survei Kepuasan Masyarakat (SKM) untuk perilaku pelaksana sebesar 3.05 dengan nilai konversi SKM sebesar 76.25 yang bermakna kurang baik.

8. Penanganan Pengaduan, Saran dan Masukan kantor desa Tatah Layap Kecamatan Tatah Makmur Kabupaten Banjar

Penanganan pengaduan, saran dan masukan Kantor Desa Tatah Layap Kecamatan Tatah Makmur Kabupaten Banjar dijabarkan dalam pernyataan mengenai saran dan masukan masyarakat terhadap petugas pelayanan. Hasil penelitian menunjukan bahwa penanganan pengaduan, saran dan masukan Kantor Desa Tatah Layap Kecamatan Tatah Makmur Kabupaten Banjar belum baik. Hal tersebut dapat dilihat dari nilai Survei Kepuasan Masyarakat (SKM) untuk penanganan pengaduan, saran dan masukan sebesar 3.06 dengan nilai konversi SKM sebesar 76.50 yang bermakna kurang baik.

9. Sarana dan Prasarana kantor desa Tatah Layap Kecamatan Tatah Makmur Kabupaten Banjar Sarana dan prasarana kantor desa Tatah Layap Kecamatan Tatah Makmur Kabupaten Banjar dijabarkan dalam pernyataan mengenai sikap fasitilas yang diberikan kantor desa terhadap masyarakat yang ingin mendapatkan pelayanan. Hasil penelitian menunjukan bahwa sarana dan prasarana Kantor Desa Tatah Layap Kecamatan Tatah Makmur Kabupaten Banjar belum baik. Hal tersebut dapat dilihat dari nilai Survei Kepuasan Masyarakat (SKM) untuk Sarana dan prasarana sebesar 2.92 dengan nilai konversi SKM sebesar 73.00 yang bermakna kurang baik.

Tindakan yang harus dilakukan Kantor Desa Tatah Layap Kecamatan Tatah Layap Kecamatan Tatah Makmur Kabupaten Banjar Terhadap Hasil Survei Tersebut:

a. Persyaratan Pelayanan Kantor Desa Tatah Layap Kecamatan Tatah Makmur Kabupaten Banjar

Berdasarkan hasil Survei di atas bahwa persyaratan pelayanan Kantor Desa Tatah Layap Kecamatan Tatah Makmur Kabupaten Banjar baik. Akan tetapi ada beberapa masyarakat masih menganggap persyaratan pelayanan masih kurang. 
Berdasarkan uraian tersebut perlu dilakukan upaya untuk terus meningkatkan sosialisasi persyaratan pelayanan Kantor Desa Tatah Layap Kecamatan Tatah Makmur Kabupaten Banjar dalam proses pelayanan dengan cara ketua RT harus lebih aktif dalam hal mensosialisasikan persyaratan pelayanan ke masyarakat agar masyarakat lebih mengetahu apa saja persyaratan yang harus diperlukan.

b. Prosedur pelayanan Kantor Desa Tatah Layap Kecamatan Tatah Makmur Kabupaten Banjar

Berdasarkan hasil Survei di atas menunjukan bahwa prosedur pelayanan Kantor Desa Tatah Layap Kecamatan Tatah Makmur Kabupaten Banjar baik.. Akan tetapi ada beberapa masyarakat masih menganggap prosedur pelayanan masih kurang dalam proses pelayanan. Berdasarkan uraian tersebut perlu dilakukan upaya untuk terus meningkatkan prosedur pelayanan Kantor Desa Tatah Layap Kecamatan Tatah Makmur Kabupaten Banjar dengan cara Kantor Desa Tatah Layap Kecamatan Tatah Makmur Kabupaten Banjar harus membuat atau memiliki teks, tulisan atau gambar dalam tahapan alur pelayanan agar masyarakat lebih mudah dalam mengetahui prosedur pelayanan.

c. Waktu Penyelesaian Kantor Desa Tatah Layap Kecamatan Tatah Makmur Kabupaten Banjar

Berdasarkan hasil Survei di atas menunjukan bahwa waktu penyelesaian Kantor Desa Tatah Layap Kecamatan Tatah Makmur Kabupaten Banjar kurang baik. Berdasarkan uraian tersebut, perlu dilakukan upaya untuk meningkatkan kecepatan penyelesaian di Kantor Desa Tatah Layap Kecamatan Tatah Makmur Kabupaten Banjar dengan cara peningkatan mutu pelayanan dengan cara Kantor Desa Tatah Layap Kecamatan Tatah Makmur Kabupaten Banjar harus membuat standar waktu untuk kategorisasi waktu penyelesaian agar standar waktu penyelesaian dapat dipahami oleh masyarakat, dan Kantor Desa juga dapat menyelesaikan waktu pengerjaan sesuai standar waktu yang sudah dibuat.

d. Biaya/Tarif Kantor Desa Tatah Layap Kecamatan Tatah Makmur Kabupaten Banjar

Berdasarkan hasil Survei, menunjukan bahwa biaya/tarif Kantor Desa Tatah Layap Kecamatan Tatah Makmur Kabupaten Banjar baik. Akan tetapi ada beberapa masyarakat masih menganggap biaya/tarif masih kurang dalam proses pelayanan. Berdasarkan uraian tersebut perlu dilakukan upaya untuk terus meningkatkan pelayanan tanpa mempertimbangkan biaya/tarif pelayanan Kantor Desa Tatah Layap Kecamatan Tatah Makmur Kabupaten Banjar dengan cara pertahankan kejujuran dan bebas pungli agar masyarakat lebih puas dalam kepengurusan tanpa pungutan biaya apapun.

e. Produk Spesifikasi Jenis Pelayanan Kantor Desa Tatah Layap Kecamatan Tatah Makmur Kabupaten Banjar

Berdasarkan hasil survei diatas menunjukan bahwa produk spesifikasi jenis pelayanan Kantor Desa Tatah Layap Kecamatan Tatah Makmur Kabupaten Banjar baik. Akan tetapi ada beberapa masyarakat masih menganggap petugas kurang baik dalam proses pelayanan. berdasarkan uraian tersebut, perlu dilakukan upaya untuk terus meningkatkan pelayanan di bidang produk spesifikasi, jenis pelayanan Kantor Desa Tatah Layap Kecamatan Tatah Makmur Kabupaten Banjar dengan cara Kantor Desa lebih mensosialisasikan lewat ketua RT atau pun dari papan-papan pengumuman yang ada disekitar Desa Tatah Layap Kecamatan Tatah Makmur Kabupaten Banjar tentang produk jenis pelayanan nya apa saja yang ada di Kantor Desa Tatah Layap Kecamatan Tatah Makmur Kabupaten Banjar. 
f. Kompetensi Pelaksana Kantor Desa Tatah Layap Kecamatan Tatah Makmur Kabupaten Banjar

Berdasarkan hasil survei diatas menunjukan bahwa kompetensi pelaksana Kantor Desa Tatah Layap Kecamatan Tatah Makmur Kabupaten Banjar baik. Akan tetapi ada beberapa masyarakat masih menganggap petugas kurang baik dalam proses pelayanan. Berdasarkan uraian tersebut, perlu dilakukan upaya untuk terus meningkatkan kompetensi pelaksana Kantor Desa Tatah Layap Kecamatan Tatah Makmur Kabupaten Banjar dengan cara mengikuti pelatihan-pelatihan dari pemerintah, selain itu juga aparatur desa dapat studi banding ke wilayah desa yang sudah maju agar dapat pengetahuan,keahlian baru dalam melayani masyarakat.

a. Perilaku Pelaksana Kantor Desa Tatah Layap Kecamatan Tatah Makmur Kabupaten Banjar

Berdasarkan hasil survei diatas menunjukan bahwa perilaku pelaksana Kantor Desa Tatah Layap Kecamatan Tatah Makmur Kabupaten Banjar kurang baik. Berdasarkan uraian tersebut, perlu dilakukan upaya untuk meningkatkan kesopanan dan keramahan petugas dalam memberikan pelayanan di Kantor Desa Tatah Layap Kecamatan Tatah Makmur Kabupaten Banjar dengan cara meningkatkan sumber daya aparatur dan diperlukan sikap dan mental yang baik dari setiap aparatur pemerintah yang langsung berhadapan dengan masyarakat dalam memberikan pelayanan dan kepala desa juga harus mengawasi kinerja dari aparatur desa dalam melayani masyarakat.

b. Penanganan Pengaduan, Saran dan Masukan Kantor Desa Tatah Layap Kecamatan Tatah Makmur Kabupaten Banjar

Berdasarkan hasil survei diatas menunjukan bahwa penanganan pengaduan, saran dan masukan Kantor Desa Tatah Layap Kecamatan Tatah Makmur Kabupaten Banjar kurang baik. Berdasarkan uraian tersebut, perlu dilakukan upaya untuk meningkatkan penanganan pengaduan, saran dan masukan dari masyarakat, dengan cara hasil dari kotak saran hendaknya di evaluasi seminggu sekali agar dapat mengetahui keinginan masyarakat terkait dengan pelayanan yang diberikan oleh Kantor Desa Tatah Layap Kecamatan Tatah Makmur Kabupaten Banjar sehingga dapat mewujudkan harapan masyarakat.

c. Sarana dan Prasarana kantor desa Tatah Layap Kecamatan Tatah Makmur Kabupaten Banjar

Berdasarkan hasil survei diatas menunjukan bahwa sarana dan prasarana Kantor Desa Tatah Layap Kecamatan Tatah Makmur Kabupaten Banjar kurang baik. Berdasarkan uraian tersebut, perlu dilakukan upaya untuk menambah fasilitas di Kantor Desa, serta melakukan pembenahan pada fasilitas sarana dan prasarana yang masih dianggap kurang nyaman oleh masyarakat. Kantor Desa hendaknya menyediakan fasilitas-fasilitas yang mendukung seperti parkir yang nyaman, bangku antrian di sediakan, agar masyarakat lebih nyaman dalam hal mendapatkan pelayanan.

\section{Kesimpulan}

Berdasarkan hasil penelitian dan pembahasan diatas dapat disimpulkan bahwa berdasarkan perhitungan survei kepuasan masyarakat yang mengacu pada PERMENPAN RB Nomor 14 Tahun 2017, maka diperoleh hasil nilai konversi SKM sebesar 76.75 yang berada pada interval 76.61 - 88.30, sehingga kepuasan masyarakat terhadap pelayanan publik di Kantor Desa Tatah Layap Kecamatan Tatah Makmur Kabupaten Banjar berada pada tingkat 
"B". Hal ini menunjukan bahwa kinerja pelayanan Kantor Desa Tatah Layap Kecamatan Tatah Makmur Kabupaten Banjar tahun 2018 secara keseluruhan termasuk kategori baik. Dari 9 (Sembilan) unsur yang ada di permenpan RB Nomor 14 Tahun 2017 ada 4 (empat) unsur menurut masyarakat kurang baik. Yaitu unsur waktu penyelesaian dengan nilai konversi SKM sebesar 73.25, unsur perilaku pelaksana dengan nilai konversi SKM sebesar 76.25, unsur penanganan pengaduan, saran dan masukan dengan nilai koversi SKM sebesar 76.50, unsur sarana dan prasarana dengan nilai koversi SKM sebesar 73.00. SElanjut nya ada 5 (lima) unsur menurut masyarakat baik. Yaitu unsur persyaratan dengan nilai konversi SKM sebesar 80,25, unsur system, mekanisme dan prosedur dengan nilai konversi SKM sebesar 79.50, unsur biaya/tarif dengan nilai konversi SKM sebesar 80.50. unsur produk spesifikasi jenis pelayanan dengan nilai konversi SKM sebesar 79.75, unsur kompetensi pelaksana dengan nilai konversi SKM sebesar 79.25.

Dari hasil survei kepuasan masyarakat tersebut tindakan yang harus dilakukan Kantor Desa Tatah Layap Kecamatan Tatah Makmur Kabupaten untuk ke 9 (sembilan) unsur Permenpan RB No 14 tahun 2017 yaitu dengan cara petugas lain bisa bisa lebih aktif memberi arahan kepada masyarakat yang ingin mendapatkan pelayanan agar masyarakat lebih mudah dan paham dalam petunjuk alur pelayanan, peningkatan mutu pelayanan melalui sumber daya manusia yang berkualitas, perlu adanya strategi baru untuk meningkatkan waktu penyelesaian yang lebih efektif dan efisien misalnya penghargaan bagi pegawai yang berprestasi, selain itu juga kepala desa hendaknya mencek pekerjaan pegawai secara berkala agar pelayanan kepada masyarakat lebih diutamakan dan waktu penyelesaian lebih cepat lagi, aparatur lebih banyak mengikuti pelatihan-pelatihan dari pemerintah, selain itu juga aparatur desa dapat studi banding ke wilayah desa yang sudah maju agar dapat pengetahuan,keahlian baru dalam melayani masyarakat dan fasilitas di Kantor Desa di sediakan agar masyarakat lebih nyaman dalam mendapatkan pelayanan.

\section{DAFTAR PUSTAKA}

Agustina (2013) Indeks Kepuasan Mayarakat Terhadap Unit Pelayanan Kantor Kecamatan Tulungagung

Abshor Muhammad Rizky Ariani (2015) dengan judul analisa Survey Kepuasan Masyarakat pada Badan Pelayanan Perijinan Terpadu dan Penanaman Modal Kota Banjarbaru.

Gaspesz,Vincent. (2011). Total Quality Management (untuk Praktisi Bisnis dan Industri). Bogor: Vinchristo Publication.

Hidayat Rahmad (2016) Analisis Masyarakat Terhadap Pelayanan di Kantor Kecamatan Tapin Utara Kabupaten Tapin.

Irwansyah Ramadhan (2014) Indeks Kepuasan Masyarakat pada Pelayanan Publik di Kelurahan Bungur Jakarta Pusat

Keputusan Mentri Pendayagunaan Aparatur Negara Nomor :Kepmenpan/14/2017 Tentang Pedoman Umum Penyusunan Indeks Kepuasan Masyarakat Unit Pelayanan Instansi Pemerintah

Ratminto dan Atik Septiwinarsih ,(2012) Manajamen pelayanan

Mahmudi (2013) Manajemen Kinerja Sektor Publik, Sekolah Tinggi Ilmu Ekonomi Manajemen YKPN Yogyakarta

Nugraheni, Zulfi Ahaditya Arif, (2015) Analisis Kepuasan Masyarakat Terhadap Pelayanan Publik Berdasarkan Indeks Kepuasan Masyarakat di Kantor Kecamatan Mungkid, Kabupaten Magelang

Sinambela Litjan Poltak dkk (2011) Reformasi Pelayanan Publik Jakarta

Undang-Undang RI No. 25 Tahun 2009 
Utami Wijayanti Setyo dan suryanto (2013) dengan judul Indeks Kepuasan Masyarakat pada Pelayanan Kantor Kecamatan di Surakarta

Wijayanti Setyo Utami dan Suryanto (2013) Indeks Kepuasan Masyarakat pada Pelayanan Kantor Kecamatan di Surakarta, Indonesia 